\title{
Obesity , Abuse Feeding, Over Usage Of Chemic-Pharmaceutical Medications, Extracts And Other Factors
}

\author{
M. Agolli \\ University "Eqrem Çabej", Gjirokastra, Albania \\ M. Terpo \\ University “Eqrem Çabej”, Gjirokastra Albania \\ Email: agollimaria@yahoo.com \\ Dh. Terpo \\ E. Meçi \\ University "Eqrem Çabej”, Gjirokastra Albania \\ Email: agollimaria@yahoo.com
}

Doi:10.5901/mjss.2014.v5n13p235

\begin{abstract}
Obesity or "syndrome $X$ " is a contemporary character that the disease is spreading more and more. Today in the world numbering over 250 million obese. It is characteristic disease of the century that has conquered the globe where there is reason to take the name "globesyity" Take measures against the spread of this syndrome begins and continues with the determination and the exact meaning what's obesity. Obesity is a metabolic shock triglyceride resulting in the addition of excess adipose tissue in the body generally beyond the amount that is necessary for normal functioning. The purpose of this paper is to generate some conclusions about: - What is besity. -The form 's format of his complications. - Preventive measures, therapy. The most important preventive measures against obesity are after "disaster" of the occurrence of obesity is necessary to take measures to combat it and what is more difficult.
\end{abstract}

Keywords : obesity , metabolic shock, complications, therapy

\section{Introduction}

Obesity today has become global disease. Over time it is spreading more and more all countries including developed and developing countries.

Super food consumption and calories, build-up of its production and industrialization in each stage, the abundance of foods, particularly processed, dismissals hand, sedentary way of life without movement outdoor fresh air are among the causes basic contemporary shogërisw this disaster.

According to $\mathrm{WHO}$ in the world, numbering more than 250 million obese, ranging from children to the elderly.

In America, over 50\% of people are over normal weight, in Europe 19\% of men and $24 \%$ of women are obese. NQ serious problem worldwide is obesity in children. In France, Italy and Greece respectively 1 to 7,1 to 4 and 1 to 5 children are obezw. These are "children fetched food and refreshments" (Hopisler)

Obesity now affects at least $15 \%$ of the population worldwide are determined diseases such as those of the heart, breathing, gallstones, diabetes, particularly mëlçisw gjëndror system, thyroid, etc., to a nervous and psychological character.

Obesity is indeed characteristic of the disease that has invaded century globe and has received the name of "globezitet" but not excluded and its historic character.

Since the V century BC, Hippocrates noted that sudden death is more characteristic to obese people, but the same thing noted in the Roman Galinari disease called "cessation of breathing in sleep" which was noticed as he said in most cases overweight people.

The opinion of the majority of researchers in this field is that preventive measures are not taken IF millennium we are going through will be the era of obesity.

While most authors consider the special peshwn syndrome or syndrome " $\mathrm{X"}$ 
Taking measures against the spread of this syndrome starts and continues with determination and precise meaning than was obesity

Obesity is a metabolic shock triglyceride resulting in the addition of excess adipose tissue in the body generally beyond the amount that is necessary for normal functioning. Over weight $d$, ekulibron whole metabolism, physiological function of organs by providing the thrill of a general character, and it involves the nervous system which is reflected in agony, depression, lack of interest, low self-esteem and to aggressively toward others and themselves. Among the causes that lead to obesity are:

\section{Genetic Predisposition}

Most recent studies found that there is gene directly related obesity. This gene determines production of protein called leptin, which is naturally higher in obese children and adults. In obese children it is 4 times higher than normal children. Leptin through encefalike centers gives the message of hunger or satiety by its productivity level.

Oneself or increased appetite is directly linked to increasing obesity and determined according to recent data from the so-called "appetite hormone" or as it is called grelina which is produced in the stomach.

Its Podhimi added before meals and after meals reduced by a specified equilibrium ` $d$ normally but bringing about a balance of this product directly reflected in the consumption of nutrition by increasing it from $30 \%$ to $50 \%$. weight.

This "hormone" according to researchers is directly responsible for recovering the lost kilos fast after a falling

The effect of this "hormone" in normalizing weight has a time span in both directions as in the over weight and weight reduction on but in the first case the effect is faster, that is why today the attention of researchers is led to the discovery of factors that determine the production of this hormone or as many authors cite successes in this area are closely related to the effective fight against obesity.

\section{Forms of Obesity}

Obesity in terms morfologjiko-cell appear in two types:

Hipertrofik obesity which is characterized by the increase in the size of lipoqelizave.

Hiperplastik obesity characterized by the increase in numwr lipoqelizave.

Obesity in children generally faces he hiperplastik or increasing the number of lipoqelizave what constitutes and "disaster" of a child destined to become obese and an obese adult.

Obesity affects all ages but there are some that are most critical age. of obesity.

First in the period of life up to 2 - years become physiologically lipoqelizave increased without determining effects

Periods are from 3 years old to puberty is decisive for the future preservation of body weight. In this period of overweight children increased excess observed when children lipoqelizave pwrtej feed rates allowed. Over weight gain in this periodw remains for a long period of time. When children are obese in this period the chances are that in $80 \%$ of cases end tw obese for life.

After 25 years obesity is almost no form hipertrofik additional lipoqelizave, but become characteristic increase their size and dominance of its positive direction through treatments become more mundshën.

\section{Complications of Obesity}

Money and direct complications of obesity are:

- Hiperurinemia, which means in itself increase the concentration of uric acid in the blood which is associated with major complications in all organs tw circulatory system.

- Increased blood lipids like cholesterol free, triglycerides, phospholipids and free fatty acids, whose deposition in the blood vessels of these serious harms by gëlqerizuar degenerate to jam.

- Increased blood glucose and diabetes trend towards permanent display of hard-to cure.

\section{Obesity in Children}

When we talk about obesity in children it is a serious problem with a significant impact on the future on the world stage. Wholesale fat deposition is associated with numerous permanent consequences of very long time, and unfortunately 
hardly repairable in most cases unchanged throughout life. Children as the main causes of obesity are those of a general starting from the basics.

Excessive food ei content concentrated in fats, sugars and calories multiple, low standard of nutrition not only in content but also the combination of foods, food unbalanced mass use of ready meals and semi-finished.

Lack of exercise movements in the fresh air, especially in nature.

Lack of recognition that child and family economic situation.

The consequences of obesity in children unfortunately are immutable consequences for the coming age being added to older age groups. They sustained injuries related to heart, blood vessels, gjëndror system, not the achievement of relevant parameters to children under age but also with widespread psychological damage of the nerve. For some types of cancer occurrence as confirmed by most researchers and authors ndryshënm is responsible obesity as a disease in itself but in particular its consequences.

\section{Obesity in Adults}

Obesity in adults wshtë hipertrofik type. He appears as a continuation of the disease (type hyperplastiC) at younger ages with all the negative consequences that characterize. Evil is the most growing deterioration comes from the placement of character hipertrofik obesity. Displayed as a particular type that is compatible with that of increasing the age of lipcells.

Table No. 1. Frequency of obesity nw some places tw botws..

\begin{tabular}{|l|c|c|}
\hline Different countries & Males & Females \\
\hline Northern europe & $10 \%$ & $15 \%$ \\
\hline Western europe & $13 \%$ & $16 \%$ \\
\hline Mediterranean countries & $16 \%$ & $30 \%$ \\
\hline Eastern europe & $18 \%$ & $30 \%$ \\
\hline U.s.a whites & $8 \%$ & $15 \%$ \\
\hline U.s. Colored & $20 \%$ & $37 \%$ \\
\hline
\end{tabular}

From the analysis of the resulting data table anywhere in the world that women are more prone to obesity than men. This is explained by the large loads of great physiological and hormonal changes which are subject to the female sex. Certain period of birth as it's leaving the children, the rest of the development cycle in women are closely linked with the tendency toward obesity.

Without doubt the most peaceful forms of life lack of movement, leaving work, little consumption of calories taken, method of feeding, forced usage of the residue of drugs have major impact on the appearance but especially to severe obesity in old age.

When it comes to obesity in adults has more data and studies, reasoning and conclusions, and often different but one thing everyone agrees fall IF need to protect ourselves from old age in general and in particular the earliest it should to fight obesity by all means

\section{Therapy Against Obesity}

When prevention fails and the object are in front of an obese person should first through an analysis of clinical and psychological therapy is undertaken properly:

The first measure starts from the simple; The person concerned must be freed from old habits of nutrition treatment that have led to this situation.

Losing weight goal remains the first and foremost being fully aware that this is not an easy job but quite difficult and complicated to be timely and great perseverance.

The diet should be as intentionally reducing weight through a rigorous definition and implementation of measures in terms of quantity and composition of food. It can be used very effectively in fighting obesity ie when the pasha average does not exceed $20-25 \mathrm{~kg}$. In these cases the controlled more easily borne some metabolic disorders characteristic of age and diabetes, hipertensionim, hyperlipidemia etc..

A diet is considered successful when weight changes (decreasing) are small and gradual. Changes rather sudden and large are not stable and are associated with other disorders side of

often quite dangerous. 
Put clearly considered a good diet consisting of foods called "hygienic" as grains, herbs, fruits, seafood, milk in cream form, natural juices etc. avoiding foods "unhealthy" as prepared foods, tinned, dried, salted, chocolate cakes, alcohol, juices and in particular industrial foods with high fat content.

\section{Physical Activity}

This includes any kind of movement that can work normally borne steadily since that simple movement of the foot in the air Pater steadily, walking athletic gymnastics through which the excess calories consumed but also ensure a state of good functioning of the whole organism.

Combining physical activity with diet is a good way of reducing weight marking results essentially stable for many years.

\section{Pharmaceutical Therapy}

Is known as a method for combating obesity and excess weight reduction. Many people also turn to this type of training which recommended a limited and lesser forms since all known pharmaceutical drugs that can be used for reducing weight are noted for strong side effects and harmful.

It is for this reason that these medications are increasingly abandoned due to negative indications that accompanied their use even limited.

\section{Surgical Therapy}

Performed in extreme cases when other methods are not working and when the pasha exceed 40 kilograms. And has a consistency more than 5-years.

In these cases, patients should be aware of important changes in their lives. The decision to take this kind of therapy when the expected advantages of the potential danger passes and the 16-65 years age limits. In conclusion we can say that:

- Obesity is the disease most modern broadband characteristic of the largest ever.

- Interaction with each one of us individually heritage obesity and specific pathologies mostly has to do with the fact "we know we know we eat or eat".

- In the case of children it has to do with lack of knowledge on how parental feeding.

- Obesity in adults is influenced and exacerbated more by not report template in food consumption.

- Movement and exercise remain the most natural action and more effective against obesity.

\section{References}

Alerksamdhropullos Thomas "Themata higjiinis trofimon qe dhiatrofis("Tema të higjienës ushqimore dhe të të ushqierit") Dhervisogllu Qirjaqi "llektrotherapia-Esthitiqi Somatos"("Elektroterapia-Astetika e Gojës" Thesalloniqi, Panepistimiaqes Paradhosis,2003 Zilidhis Hristos Dh. "Dhiatrofi qe dhimosia Hijia"("Të ushqierit dhe Shëndeti public") Thesalloniqi,University Studio Press ,1995 Piperaqis Stelios "Trofi,Dhiatrofi,Anatrofi.I dhiatrofiqes synithies.Enimerosi.Ekpedhefsi.Tropos zois".("Ushqim,Të ushqyerit,Rritja,Zakonet e të ushqierit,Informimi,Edukimi,Mënyra e jetesës") Athina,Tipothito,2002

Savvidhu Anna "Pahisarqia-Qitaritidha-mallaksi"(Obeziteti-Citaroza-Masazhi") Thesalloniqi,Penepistimiaqes Paradhosis,2007 Hasapidhu Maria,Ciringjiroglu-Fahantidhu Anna "Dhiatrofi ja hijia,asqisi qe athlitismo"( "Të ushqierit për shëndet,stërvitje dhe atletikë) Thesalloniqi ,University Studio Press,2002 